Vol. 3: (June) 2013

\title{
Mahdi Elmandjra and the Future of the Muslim World
}

\author{
WAN FARIZA ALYATI WAN ZAKARIA ${ }^{1}$
}

\begin{abstract}
The increasing problems and challenges facing the Muslims and the Muslim world nowadays have raised serious concern about the future of the Muslims and the Muslim World among many Muslim scholars. The post-Iranian Islamic Revolution in 1979 had always been seen as the landmark of the rising discourses over the future of Islam, Muslims and the Muslim world. Mahdi Elmandjra, a prominent sociologist and futurist, is one of the Muslim scholars who consistently discuss about the issue and urge the Muslims to take responsibility to create a better future in a systematic way and not to fall into the vicious cycle of misfortunes. This paper aims at discussing Elmandjra's views on this issue and underscoring the contribution and significance of such discourse within contemporary development.
\end{abstract}

Keywords: Arab World, future studies, Mahdi Elmandjra, Muslim world

Mahdi Elmandjra, a prominent sociologist and futurist, is one of the Muslim scholars who consistently discuss about the future of the Muslims and the Muslim world. Elmandjra was born in Rabat in 1933. He graduated from Cornell University and obtained his doctorate from the London School of Economics. He was the Director General of the Moroccan Broadcasting Service and Counselor of the Moroccan Mission to the United Nation. Between 1961 to 1981, he occupied various functions in the United Nation System including the Assistant Director General of UNESCO for Social Sciences, Human Sciences and Culture and the Coordinator of the Conference on Technical Cooperation among Developing Countries (UNDP) (http://www.elmandjra.org/summary.htm). He was also the President of the World Future Studies Federation and of Futuribles International of Paris as well as the Founding President of the Moroccan Association of Futures Studies and the Moroccan Organization for Human Rights. He has been a Visiting Professor of Tokyo University (1998) and a Visiting Scholar of the Japanese Society for the Promotion of Science (JSPS) at the Tokyo Keizai University (1999) (http://www.elmandjra.org/summary.htm).

Elmandjra has published over 400 articles in the fields of the human and social sciences. He is a co-author of "No Limits to Learning" (Report to the Club of Rome 1979) and the author of several books including The United Nations System, Maghreb et Francophonie, Premiere Guerre Civilisationnelle, Retrospective des Futurs, Nord-Sud, Prelude a l'Ere Postcoloniale, Cultural Diversity Key to Survival, Dialogue about Communication, Decolonisation Culturelle: Defi majeur du 21e Siele, Al-Quds Al-Arabi, Path of a Mind, Reglobalization of Globalization, and Intifadate, to name a few (http://www.elmandjra.org/summary.htm).

Throughout his intellectual and professional life, he has been designated to various important positions for his outstanding scholarship, such as the President of the World Future Studies Federation (WFSF) (1977-1981), the President of the Futuribles International (19811990), and the President of the Club of Rome (resigned in 1988). He was also members of various institutions such as the Academy of the Kingdom of Morocco, the World Academy of Art and Science, the World Academy of Social Prospective, the Moroccan Association of Economists, the Moroccan Association of Philosophy, and the Moroccan Association of Historians. He was also the Founding President of the Moroccan Association of Futures Studies, the Moroccan

\footnotetext{
${ }^{1}$ Wan Fariza Alyati Wan Zakaria, Ph.D., Senior Lecturer at Department of Theology and Philosophy, Faculty of Islamic Studies, Universiti Kebangsaan Malaysia, 43600 BANGI Selangor, Malaysia. Email: aufaa@ukm.my.
} 
Organization for Human Rights and the Founding Member and the Vice President of the Morocco-Japan Association. He was also the Executive Committee of the African Academy of Sciences and the Pugwash Movement and Council for the Society for International Development between 1982 to 1988 and its Executive Committee between 1985 until 1988. With all these significant contributions to the world society, he was chosen by the International Biographical Center as one of the "2000 Outstanding Scholars of the 20 2 th Century" (http://www.elmandjra.org/summary.htm).

\title{
Islam and the Future
}

The source of Elmandjra's thought derived from the Islamic sources when he refers to the Quranic verses ${ }^{2}$ and conception of future in claiming the importance of futures thinking. He emphasizes that in Islamic discourse on the future, there are a few concepts that should be understood correctly. Such concepts, as he discusses them briefly, is the concept of 'al-ghayb' (unknown) which he believes within the realm of God and 'mustaqbal' (future) which for him implies the anticipation of developments arising from people's action or inaction. He also asserts the difference between the concept of 'bid'ah' (heresy) and 'ibda 'a' (innovation) in which, "...the first is an opinion or attitude which is in violation of the basic tenets of Islam...", whereas "...the second is, on the contrary, an invitation to introduce changes and innovations in order to stimulate the community's development and vitality" (Elmandjra 1990: 3).

The other concept, which is in fact the most obvious and significant one, is the Islamic vision of life on earth and also in the hereafter for it calls for the human being "...to seek command of his own fate and to adopt, for this purpose, a dynamic approach in his political, economic, social and cultural initiatives". In relation to this, is the concept of change, in which Elmandjra (1990: 3) regards as an essential ingredient for a better future. Furthermore, he stresses that the Prophet's actions demonstrated his forward looking attitude towards life and his prophetic mission. Elmandjra (1990: 2-3) concludes thereby that:

\begin{abstract}
All these verses from the Quran call us to make the best possible use of the present and to carefully and intelligently prepare for the future; the future meaning the rest of our life on earth and the hereafter... [the Quran] recommend[s] that we make projections and work out different options in order to enhance our ability to cope with the requirements of the future and to improve our well-being. Therefore the future should be approached in a pluralistic manner (futures) thus leaving open a wide range of options. Islam is a faith and a way of life. It is also an exploratory vision of life on earth and in the hereafter. It is our outlooks that determine our deeds for which we are answerable to ourselves, to society and to God. In Islam Man, whatever he does, is mindful of the impact of his action on the rest of his life as well as on his fate in the Last Judgment.
\end{abstract}

\footnotetext{
2 "Oh ye who believe! Observe your duty to Allah. And let every soul look to that which it sent on before for the tomorrow" (al-Quran, al-Hasyr 59:18); "Have they not seen how We have appointed the night that they may rest therein, and the day sight-giving? Lo! Therein verily are portents for a people who believe. And (remind them of) the Day when the Trumpet will be blown, and all who are in the heavens and the earth, will start in fear, save him who Allah wills. And all come unto Him, humbled. And you will see the hills you deemed solid flying with the flight of clouds: the doing of Allah who perfected all things. Lo! He is informed of what ye do" (al-Quran, al-Naml 27: 86-88); "Send him with us tomorrow that he may enjoy himself and play. And Lo! We shall take good care of him"(al-Quran, Yusuf 12:12); "And say not of anything: Lo! I shall do that tomorrow," (al-Quran al-Kahf 18: 23); "No soul knows what it will earn tomorrow, and no soul knows in what land it will die"; (al-Quran al-Sajdah 32: 34); "Tomorrow they will know who is the rash liar" (al-Quran, al-Qamar 54: 26). - quoted by Elmandjra in "The Future of the Islamic World', A paper presented in the Symposium on The Future of the Islamic World, Algiers, 4-7 May 1990, pp:1-2.
} 
Vol. 3: (June) 2013

\title{
The Muslims World and the Future
}

Elmandjra (1990: 4) believes that Islam is a powerful factor of change and innovation, hence play a vital role in the evolution of the Muslim society. He argues that "...the future of the ArabIslamic world depends on the revival of Islam in its innovative acceptance, not Islam of blind imitation which led to the fall of a once brilliant civilization". In fact, he reasons that "...if the Prophet Muhammad and his companions had failed to imagine and visualize the future, there would probably not be as many as 1,200 million Muslims in the world today".

However, despite the very fact that Islam has greatly changed the Arab Jāhili world of 1,300 years ago, it seems extremely incomprehensible to think of how once a powerful force could not affect and offer the same remedy to the present Arab - and similarly to the rest of the Muslim world today, unless, using the case of the doctor and patient analogy, the problem underlies in the patient's own demur. This is what happen in the Arab, and the Muslim world today. Upon coming to this conclusion and as far as Elmandjra's futures' idealism is concerned, his analysis pertaining to the future of Islam is approached from three different circumferences: the problems and the future of the Arab world; the problem and the future of Islam in Europe and; the problem and the future of the Muslim world.

In analyzing the future of the Arab world, Elmandjra stresses explicitly that "...the Arab world is not presently master of its own destiny" (Elmandjra 1990: 3). He argues that this fact is true because of many reasons, one of which is the result of its past and still affecting the present and conditioning its future. The most salient features of the Arab world today, as Elmandjra figures it, is the nature of atomization of its states that has remained one of the primal conundrum facing the region, whereby "...eighty percent of the total Arab population is concentrated in 7 countries whereas 7 other countries barely reach 2 percent of that total" (Elmandjra 1990: 2). He says:

\begin{abstract}
This geopolitical fragmentation is the consequence of a harmonized colonial AngloFrench plan, after the dismemberment of the Ottoman Empire, including the Sykes-Picot Agreement (1916), the Balfour Declaration concerning Palestine (1917) and the Armistice Treaty (1918) which has transformed the region into a mosaic of artificial kinglets and mini-territories well endowed with oil. At Balkanization which is reflected today in an unequal distribution of income in the region - from less than $\$ 500$ dollars (Somalia, Yemen, Mauritania) to over \$20.0000 dollars (United Arab Emirates and Kuwait). The image people have about the richness of the Arab world needs to be relativized. The total GDP of the Arab countries ( $\$ 500$ billion dollars) is not even equal to the GDP of Spain and represents only one fourth of the GDP of Germany (Elmandjra 2004).
\end{abstract}

Following the abovementioned argument, Elmandjra concedes that the major cause of the Arab problem is oil, since it arouses among major international politico-economic interests as well as the implementation of what he calls "...an exogenous model of development with an exaggerated reliance on external sources and models which stifles creativity and innovation" (Elmandjra 2004: 3). He argues that this type of development hindered the countries to become self-reliant, hence, the need for an independent Arab oil management. Furthermore, as Elmandjra points out briefly, there are other major problems that need urgent attention such as "...poverty, illiteracy, the absence of truly democratic institutions including effective mechanisms for the protection of human rights, the lack of investment in research and development and very inadequate educational and cultural policies" (Elmandjra 2004: 4).

Under those circumstances, Elmandjra proposes three different scenarios of the future. The first scenario is the 'continuity and stability scenario', which implies the continuation of the present status quo of the Arab regimes and the implementation of the 'stability' idea from the American/Western perspective. This means that the Arab-Islamic world will continue to be subjugated under Western power, which is, in other words, a linear projection of a 'colonized future.' The second scenario is the 'reformist scenario' where minimum stability prevails and an introduction of basic reforms emerges in response to the people's genuine needs and 
inspirations, but this must be enforced swiftly. The main issues that should be confronted in priority are the problems of poverty, illiteracy, economic disparity and democracy. Therefore, the intellectuals or the educated elites play a significant role and their alienation from their own cultural milieu must be rectified. The third alternative is the 'transformation scenario' in which all the three processes/scenarios are combined and bring real change whereby economic prosperity, social justice and democracy could be achieved (Elmandjra 1991: 2-4).

Therefore, in order to rectify the problems and eventually to reconstruct the Arab world in the future, Elmandjra (2004) emphasizes on the significant establishment of true democratic institutions which inspired by the people's own vision and power, not from the one exported with a "fast-food" franchise. He also stresses the need for indigenous development which derives from the people's values, aspirations, needs and visions of the future, and this should come through a democratic participatory process and involves a huge amount of work, from "...those of democratization and social justice to the most basic objectives such as food selfsufficiency, water management, fundamental education and health care". However, in the context of the Arab world, Elmandjra believes that the future will be different only through fundamental change when the supremacy of the present mega-imperial power ends and China and India become the new super powers. As Elmandjra (2004: 4) says:

The real problem is one of mental structure and the algorithms which we must yet design and develop in order to cater for our own survival. The real challenges lie in our mode of thinking and in the way we set objectives and priorities, develop prospective strategies and secure political support to turn them into tangible efforts.

El Kaidi Youssef in his article entitled Tribute to Professor Mahdi Elmandjra published in Morocco World News (2013) regards Elmandjra as "...a man of great intellect and encyclopedic knowledge. But he has not been given his due". Upon the current situation in the Arab world, El Kaidi says in regard to Elmandjra: "One of his famous 'prophecies' is what came to be known as 'The Arab Spring'. In his interviews and lectures after the first Gulf War, he used to stress that the 'intifada' in the Arab World is inevitable and it's only a matter of time. He was quite sure that the peoples of the region will surely wake up of their hibernation and topple down tyranny. He based his prophecy on the prevalent political corruption, despotism, and the lack of basic human rights. El Mahdi Elmandjra lived until he saw the dictators falling like dominoes".

The second and third approaches of Elmandjra's analysis evolve in function of at least two determinants: the future of Islam worldwide, on one hand, and the future of Europe on the other. He believes that with respect to the Muslim community living in European countries one is as important as the other, without necessarily falling into what he recognizes as a fashionable trend of 'European Islam' or 'Western Islam's discourses because the main purpose of Islam is for unity through diversity, as represented by the concept of the "ummah" whereby its boundaries are rather spiritual and socio-cultural than geographical (Elmandjra 2005a: 6). Looking from demographic perspective, Elmandjra asserts that the present and the future of Islam are both in Asia, based upon factual evidence:

The total fertility rate of the Muslim world is slightly above 3 children per woman and 30 percent of its population is under 15 years of age. By way of comparison, Western Europe has a fertility rate of 1.6 , which is below replacement, and only 17 percent of its population is under 15 . Hence the problem is not only quantitative but also qualitative

\footnotetext{
${ }^{3}$ The proponent of this discourse is no other than Tariq Ramadan through many of his books such as Western Muslim and the Future of Islam (2004) and To Be a European Muslim (1999). This idea demands a synthesis of Islam and positive aspects of European/Western values and culture and as a result, a distinct symbiosis of both worldviews and cultures. For further details of the concept of Western Muslims or European Muslims, see Tariq Ramadan, 2004, Western Muslims and the Future of Islam. (Oxford: Oxford University Press) and Tariq Ramadan, 1999, To Be A European Muslim: a Study of Islamic Sources in the European Context. (Leicester: The Islamic Foundation).
} 
Vol. 3: (June) 2013

when comparing the age pyramids. This is why according to the United Nations, Europe will need 16 million immigrants between 2000 and 2025 (Elmandjra 2005a: 6).

Noting this huge demand for young, energetic and industrious labours and workers' to maintain the present linear projection of Western economic-scientific-power achievements, Elmandjra reasons that there is no qualms that they will come from the Muslim populations of those European countries, in which consist of 7.0\% of France population; 3.9\% of Sweden; 3.4\% of Germany; $3.4 \%$ of Belgium; $2.7 \%$ of the United Kingdom; $2.0 \%$ of the Netherlands; $2.0 \%$ of Denmark; $1.6 \%$ of Norway; $1.4 \%$ of Italy, and $1.1 \%$ of Spain (Elmandjra 2005a: 6). Even more significantly, as Elmandjra continues, there are a few areas of the European lands where Muslims will outnumber their native counterparts before the year 2018 (Elmandjra 2005a: 67).

Hence, he believes that "the future of Muslims in Europe is affected by this new trend which will hopefully evolve to a greater understanding and tolerance in the future so as to ensure a minimal human dignity. This will take time...much time" (Elmandjra 2005b: 10-11). Thus for Elmandjra (2005b: 18), the problem is not that of the future of Islam which he believes will continue to thrive as indicated throughout its history and confirmed by all demographic indicators, but more importantly is "the future of Muslims in Europe", in which depends largely within their own hands through their own deeds in respecting the laws of the host countries and their patience and perseverance to mend the tarnished image of Islam.

Apart from these three regional/global dimensions of the Islamic futures, the other significant contribution of Elmandjra's thought is pertaining to the role of women in society's affairs. He firmly emphasizes that "...there is no future for Islam without the effective involvement of women" (Elmandjra 1990: 9). In his further argument for women's emancipation, he believes that part of the main reason of why the Muslim societies is lagging behind any other societies is because of the confinement of their women into a marginal role, despite the fact that Muslim women amount half of the Muslims population (Elmandjra 1990: 8). He argues that this need to be redressed through "...serious social surveys and analyses, and requires a great deal of self-criticism as as the rehabilitation of $i j t i h \bar{a} d$ resources. We must take a fresh look at the original sources of our culture, and read again and more carefully, in the light of modern developments, the teaching of the Quran" (Elmandjra 1990: 9).

Overall, Elmandjra's discussions on the future of Muslims and the Muslim world can be categorized at least under three main concerns: the condition of the present backwardness of the Muslim world as a result of their attitude and outdated mode of thinking; the need for a fresh outlook and understanding of the original sources of their culture - the Quran - and the urge for a rereading of the text in accordance to the modern development, and; the lack of vision in the Muslim societies, especially pertaining to the concept of democratic institutionalization, and the partipation of women in society and development - a waste of half of its human capital. With the current development in many of the Muslims world, especially with the Arab Spring is still gaining its momentum, it seems that change is inevitable, but the future remains uncertain. The questions are -what is the direction of this change that is being experienced by the Muslims world and what it will cost them? Explorations on the answers to these questions will shape the future of the Muslims and the Muslims world.

\section{References}

Elmandjra, Mahdi. 1973. The United Nations System: an analysis. London: Faber and Faber. 1990. The Future of the Islamic World. Algiers. 4-7 May.

1991. The Future of the Arab World: three scenarios. Al- Alam. Rabat. $2^{\text {nd }}$ January.

2004. How will the Arab World be able to master its own independent developments? Kyodo News. 25 $5^{\text {th }}$ September.

2005a. La pression de nuestro Islam, Spanish Daily “ABC". 12 $2^{\text {th }}$ September.

2005b. What future for Islam in Europe? Valencia Chapter of the Club of Rome and the Islamic Cultural Center of Valencia. $15^{\text {th }}$ September. 
Ramadan, Tariq. 2004. Western Muslims and the future of Islam. Oxford: Oxford University Press. 1999. To be a European Muslim: a study of Islamic sources in the European context. Leicester: The Islamic Foundation.

Youssef , El Kaidi. 2013. Tribute to Professor Mahdi Elmandjra. Morocco World News. $1^{\text {st }}$ January. http://www.elmandjra.org/summary.htm. [9 May 2013].

http://www.oldsite.transnational.org/SAJT/tff/people/m_elmamdjra.html. [9 May 2013]. http://www.transnational.org/forum/meet/2004/Elmandjra_ArabWorld.html. [9 May 2013]. 